\title{
Drums Sound in Hackensack: Agnes de Mille and the Jooss Ballet
}

Clare Lidbury

\section{ABSTRACT}

In 1941 Agnes de Mille created Drums Sound in Hackensack for the Jooss Ballet. There is no film of the work and few photographs but the work is documented in her choreographic notes, letters to and from de Mille, dancers' recollections, and reviews. From these can be learned why and how de Mille created the work, what it was like, and why it was significant to the Jooss Ballet. With its American theme, historical setting, dream sequence, and a female character at the center of the work it may be seen as a forgotten stepping stone in de Mille's choreographic development.

\section{KEYWORDS:}

Agnes de Mille, Jooss Ballet, Drums Sound in Hackensack, Frederick Cohen, Dartington, Trude Rittman, American Ballet

During the summer and fall of 1941, while she lived and worked in New York City, Agnes de Mille created Drums Sound in Hackensack for the Jooss Ballet. ${ }^{*}$ Her work was the first for the company by a choreographer other than Kurt Jooss, indeed, in the whole lifecycle of the Ballets Jooss only two choreographers besides Jooss created work for the company. ${ }^{\dagger}$ There is no film of the work and few photographs but the work is documented in de Mille's choreographic notes, reviews of the work, the recollections of dancers who performed in it,

\footnotetext{
* Jooss's company was known as "Ballets Jooss" in the United Kingdom and Europe and as the "Jooss Ballet" in the United States and South America. Here I use the namethat seems appropriate in the context.

† Sigurd Leeder (dancer, ballet master and Jooss’s long term collaborator/artistic partner) created Sailor's Fancy (1943) and Hans Züllig (Ballet Jooss dancer) choreographed Le Bosquet (1943).
} 
and letters to and from de Mille. From these sources it is possible to learn how and why de Mille created the work, what it was like, and why it was significant to the Jooss Ballet but seemingly of such little consequence to the choreographer that she did not mention it in her autobiography or other writings. ${ }^{*}$ With its American theme, historical setting, dream sequence, and a female character at the center of the work it would seem to have a place in de Mille's choreographic development but, so far, it has been ignored by researchers examining de Mille's work.

Jooss was not with the Jooss Ballet when de Mille worked with them for, when the company left for a tour of the US in December 1939 under a contract negotiated before the Second World War was declared, ${ }^{1}$ Frederick Cohen, the company composer, pianist and codirector was in charge. Jooss did not accompany them, "on the grounds that he wished to remain in and with England in its struggle against the Nazis." ${ }^{2}$ Subsequently, however, Jooss sought to join his company in America but, although there were repeated reports ${ }^{\dagger}$ that Jooss would soon be joining them in the US, this never happened.

In fact, it is not clear whether Jooss and de Mille ever met although de Mille remembered an incident at her October 1932 debut solo program in Paris: "At first the French didn't think I was a bit funny or even intelligible. It was Kurt Jooss who broke the horrible

\footnotetext{
* For the autobiography, please see Agnes de Mille, Dance to the Piper (New York: Da Capo Press, 1951). The New York Public Library catalogue lists an interview with de Mille in which she discusses Drums Sound in Hackensack but, in the long research period for this article, the cassette has been unavailable as it is part of a large scale digitization project with no end date in sight. No transcription exists so we cannot know what, or how much, de Mille had to say on the work.

† See, for example, Russell Rhodes, "New York Newsletter," The Dancing Times, 30, no. 356 (June 1940): 540 and "Kurt Jooss,” The Dancing Times, 32, no. 371 (August 1941): 604.
} 
stalemate halfway through the first half by jumping to his feet after the Bach Gigue and shouting "Bravo" repeatedly. As his Green Table ... was playing nightly to packed audiences in Paris, he was someone to listen to." ${ }^{3}$ However Jooss makes no mention of this event in the snippets of his autobiography or in his many interviews, and afterward, de Mille and Jooss do not appear to have crossed paths. Jooss and his company returned to Essen while de Mille, in the fall of 1932, moved on to London ${ }^{*}$ maintaining her links with the US and crisscrossing the Atlantic as work and opportunities arose during the 1930s and 1940s.

The two artists' concerns were very different at this time. De Mille worried about establishing her voice as a choreographer and performer and finding employment in the dance world that paid a reasonable salary. Jooss's problems were of a different nature; the Nazification of culture and the anti-Jewish policy began to impact him, his company, and his work. As Jooss had separated his company (some of whom were Jewish) from the employment of the city (it was now under private management with the impresarios Leon Greanin and Arnold Meckel) he was able to keep the company together. ${ }^{\dagger}$ Without state sponsorship the Ballets Jooss became, "a theatrical company, earning a living in the variable financial atmosphere of the commercial theater, ${ }^{, 4}$ and Jooss became, like de Mille, a concert choreographer trying to make a living in the commercial theater.

\footnotetext{
${ }^{*}$ Back in Essen Jooss created two new works, Big City and A Ball in Old Vienna, which, together with Pavane on the Death of an Infanta (created in 1929 to celebrate Rudolf Laban's fiftieth birthday), and The Green Table completed what has become known as Jooss's signature program. These four ballets are Jooss's only extant work.

${ }^{+}$Coincidentally, de Mille and Jooss also shared the services of Arnold Meckel for a time although de Mille despaired of him, stating in Dance to the Piper, that she felt swindled by Meckel during her time in Paris and Belgium. For Jooss, Meckel seems to have fulfilled his purpose but the company was best served by Greanin who managed them for many years.
} 
Like many other artists, Jooss found he could no longer live or work under the Nazi regime. So, as a direct consequence of increasing political pressure and activity, he and his company left Germany in secret in August $1933 .{ }^{6}$ Nevertheless, the company performed in Holland in September as previously arranged, and left for the US in October where the critics received them well. The American critic John Martin, who had seen the company when he visited Essen in the autumn of 1932, was influential in his support for Jooss's work, and especially in his glowing report on The Green Table. ${ }^{7}$ When the Jooss Ballets arrived in New York, Martin wrote informative articles in advance of the debut and complimentary reviews, and gave a voice to Jooss's political stance. ${ }^{8}$ Such was Martin's influence, through his columns in the New York Times, that, as de Mille said, "his word alone would sell or break any artist." ${ }^{99}$ Fortunately for de Mille, Martin championed her work as well, early in her career, describing her as, "one of the brightest stars" 10 of American dance.

After performing in the US, the Ballets Jooss returned to Europe and toured independently for about six months $;{ }^{11}$ when bookings ran out the company was forced eventually to disband. Beryl de Zoete, a mutual friend of Jooss and Dorothy and Leonard Elmhirst - owners of the Dartington estate and leaders of the experiment in rural reconstruction and cultural education there - acted as an intermediary, introducing one to the other. ${ }^{12}$ The Elmhirsts were "looking for an artist of international standing and experience, with a coherent philosophy of dance," 13 and Jooss "desperately need[ed] a refuge for himself and his group." Their coming together was "a combination of fortunate circumstances on both sides"14 which led not only to Jooss's move to Dartington but also to the establishment of the Jooss-Leeder School there in the summer of 1934, when Sigurd Leeder, some staff,

\footnotetext{
* Sigurd Leeder (1902-1981) worked with Kurt Jooss for over twenty years. At the start of their working together, in the early 1920s, both were dancers but, in relation to the Ballets Jooss and the training schools that existed alongside, Jooss was the recognized choreographer
} 
and over twenty students left the Folkwangschule in Essen to resume their work at the new school in England. A year or so later the Ballets Jooss was acquired by the Dartington Hall Trustees and re-founded so that Dartington became, "the home, headquarters and training ground of an international ballet [company], which it also financed." 15

At Dartington the Jooss dancers found themselves with purpose-built dance studios, The Barn Theater for performances, and excellent accommodation for everyone, all based on a 4000 acre estate of farm and woodland. In addition, and perhaps more importantly, they arrived at Dartington to find a ready-made artistic community where the arts flourished. ${ }^{16}$ Dartington gave Jooss and the company space and time to create new work, free from the demands of financial or commercial concerns. The Dartington Trust sought to make the company and the Jooss-Leeder School pay for themselves but the substantial funds of the trust, and the private wealth of Dorothy Elmhirst from which she frequently supported Jooss and his family, cushioned any major expenditure. ${ }^{17}$

What would de Mille have given for such support? One of her problems, as she saw it, was that people often thought she had similar support from the de Mille family when, from her perspective, this was not the case: She had limited financial support from her mother but not from her father or uncle, the film director Cecil B. de Mille. She certainly knew of the Elmhirsts at Dartington before her arrival, as a letter from Martha Graham to Dorothy Elmhirst states, "My dear friend Agnes de Mille brings you my greetings when she goes to dance in England. She is anxious to see Dartington too, as many of us are." ${ }^{, 18}$ De Mille must have got in contact very soon upon her arrival in England for, in a letter dated November 18,

and Leeder the teacher. Leeder continued to teach at the Jooss-Leeder School when the Jooss Ballet went to the US in 1939. He was interned and then released to Cambridge to continue working with Jooss. The two men went their separate ways in 1947 when Leeder established his own school in London. 
$1932,{ }^{19}$ Mrs Elmhirst regretfully declined an invitation to one of her performances and in turn invited de Mille to Dartington to see a dance performance. ${ }^{*}$ I have found no evidence that de Mille visited Dartington or had further contact with Dorothy Elmhirst. How different things might have been if de Mille had visited — both for her and for Jooss.

Instead, de Mille continued to try to make a name for herself in the London dance scene of the 1930s. She took ballet classes with Marie Rambert and made opportunities to choreograph and perform; she developed a great friendship with Antony Tudor and Hugh Laing with Laing later partnering her in many of her concerts. While she did not make much money, she achieved some critical acclaim; Arnold Haskell described her solo work as "really important." ${ }^{20}$ Jooss did not fare anything like as well at the hands of Haskell. The critic disparaged The Green Table which he deemed, "effective up to a point, the first time that it is seen," and declared that Jooss needed to expand his dance vocabulary. ${ }^{21}$

For her part, her friendship with Tudor and Laing underpinned de Mille's time in England. Peggy van Praagh, a fellow dancer and friend to all three recalled, "We'd see a lot of Kurt Jooss's company which we considered marvelous and very interesting." ${ }^{22}$ Can it be assumed, given the closeness of this group of friends, that de Mille attended these performances, although she makes no mention of this in her writings? Might it also be

\footnotetext{
* Prior to Jooss's arrival, Margaret Barr (1904-1991) was in residence teaching and creating work with the estate workers. Barr had been invited to Dartington by the Elmhirsts in 1930 to establish a school of Dance-Drama having studied in America with Martha Graham. During the years 1931-34, she produced dance-dramas for her students and the workers on the estate. When Jooss and his followers arrived at Dartington it was suggested that the two groups should amalgamate, a proposal that was unacceptable to both parties. Barr then left, first for London and, with the outbreak of WW II, for New Zealand, and then Australia where she created a number of successful dance-drama productions.
} 
assumed that Jooss saw her work in London-where she choreographed American themedwork such as The Harvesting, Strip Tease, Boston Brahmin, all in 1937, and, later in 1938, "an embryonic version of Rodeo., ${ }^{, 23}$ Or, had he seen her perform in Tudor's works which had specially created roles for her such as that in Dark Elegies (1937)? In truth, with de Mille moving so frequently between the US and England, with Jooss based some 150 miles from London in Devon, and so many international tours by the Ballets Jooss, it seems unlikely that their paths crossed during this time.

In September 1938, with war looming on the horizon, de Mille returned to New York. The Jooss Ballet arrived just over a year later, as de Mille was in the final stages of choreographing a piece for the first season of Ballet Theatre. Black Ritual or Obeah was her first long work—-twenty-five minutes long—set to Milhaud's La Création du Monde. It was created for Ballet Theatre's Negro Unit but performed only three times; possibly, as Carol Easton suggests, the work was, "not a failure, but it was not the success Agnes longed for.",24 With no other commissions from Ballet Theatre, de Mille set off on what was, according to her own description, a grueling but successful national tour with a company made up of herself and three dancers with Louis Horst as pianist.

Meanwhile, also in January 1940, the Jooss Ballet, including some twenty dancers, two pianists, wardrobe mistress, electrician/stage manager, impresario, and company manager, started their tour of sixty towns in an America largely unaffected by war. The repertory consisted of Jooss's signature program plus Prodigal Son (1933), Seven Heroes (1933, re-worked 1937), Ballade (1935), A Spring Tale (1939), and Chronica (1939); it was a mix of vignettes, one act ballets, and full evening works on subjects ranging from Biblical

\footnotetext{
* She lists the dancers as Sybil Shearer, Katherine Lutz and Joseph Anthony. Dance to the Piper, 258.
} 
parables to Grimm's fairy tales, and from contemporary themes to historical allegories, some of which were comic, some dramatic, and some tragic. The tour ended in April at which point there were no further bookings or chances for the company to return to England.

On his side, neither could Jooss get to his company in America as he, like so many German refugees in the UK, was interned. 'When released, in November 1940, he sought to join his company in South America, where the Jooss Ballet had been touring since May 1940. Following its opening in Uruguay, the company performed "in every South American country except Paraguay and Bolivia"26 over the next year or so, giving over 300 performances. When the extended tour ended in April 1941, Cohen was able to report both artistic and financial success although he lamented that the company had been unable to create any new works - all its time had been taken up in rehearsing the repertory or performing in order to retain financial viability. The hope that Jooss would be able to join them (bringing other ballets from the repertory or to create new works) was never fulfilled. ${ }^{27}$

Meanwhile, for Ballet Theatre's second season in February 1941, de Mille revived and revised her 1934 work, Three Virgins and a Devil. The ballet was very well received by audiences and critics alike but de Mille's only other work that season were three offBroadway performances of American Legend by the American Actors Company. The production included two American-themed numbers by de Mille, "Running Set, described as

\footnotetext{
${ }^{*}$ With the fall of France and the British retreat from Dunkirk, the British Government, in mid-May 1940, extended the protected coastal area to cover the area of south Devon, which included Dartington. Jooss was one of many of the German artists removed from there to internment camps. When released, Jooss, classified as an enemy alien, was forbidden from returning to Dartington. With the help of the Elmhirsts and the Dartington Trust he established himself, his family, and the remaining few students of the Jooss-Leeder School in Cambridge; the school soon closed but Jooss remained there for the duration of the war.
} 
"a classic square dance," and Hell on Wheels, "a play within a play with songs, dances and pantomime" based on the lives of those building the transcontinental railway in the midnineteenth century. ${ }^{28}$ Importantly, she also had a six-week engagement at the Rainbow Room, a sophisticated nightclub, where she performed with her partner Hugh Laing, now based in the US. The pair danced two numbers, both American in theme. ${ }^{29}$ De Mille disclosed in a newspaper article that it was at the Rainbow Room night club, "that Leon Greanin, manager of the Jooss troupe, and Frederick Cohen, art director [sic], approached her." 'May we have the pleasure of your next?' they put it. Said Miss de Mille: 'Delighted.'”30 This encounter begs two questions - how did Cohen know of de Mille and her work, and why did de Mille accept the commission? The answers to both these questions may lie with Trude Rittman.

Rittman, who had worked for de Mille the previous year arranging the music for her recital piece Conversations Pleasant and Unpleasant was to go on to work with de Mille on some of her most famous Broadway productions as rehearsal pianist and composer/arranger. ${ }^{31}$ Rittman first encountered dance at the Jooss-Leeder School in Dartington $^{32}$ when, already an accomplished musician and composer, she arrived as a

\footnotetext{
* During 1940/early 1941 a rift developed between Jooss and Cohen over a proposed collaboration with Trude Schoop with numerous letters, concerning legal rights to the company name and Jooss' works, existing in the Dartington Archive. It seems the situation was resolved enough by this time for Cohen and Greanin to convince Jooss to let the collaboration with de Mille proceed. The "many cablegrams" mentioned in "Jooss Dancers Back Tonight with Agnes de Mille Ballet," Brooklyn New York Eagle, October 2, 1941 are not in the Dartington Archive, however letters there from Elsa Kahl-Cohen to Dorothy Elmhirst confirm that the rift between her husband and Jooss continued for many years and was not really resolved until the City Center Joffrey Ballet performances of The Green Table in 1967.
} 
German refugee in 1933. It was at the Jooss-Leeder School that Rittman first met fellow musician and composer Fritz Cohen, musical director and chief pianist for the Ballets Jooss. ${ }^{\dagger}$

Rittman described the Jooss-Leeder approach as "very thorough and musical" and said she found herself in "exceedingly music-minded surroundings." "33 Among other musical activities she accompanied improvisation classes, composed pieces for the students' choreography exams, and although she felt the process "put [her] through the mill," it was also "very instructive" and she "fell into that pattern" 34 of improvising while the choreographer and dancers together created material. This working method came from Cohen who believed that the composer should be in the studio working alongside the choreographer as they searched for the style and form that the dramatic idea demanded. ${ }^{35}$ Thus, while Jooss worked with the dancers through improvisation and discussion, Cohen improvised at the piano until the work took shape. ${ }^{36}$ This process clearly models the way Rittman describes herself working with de Mille: "She tries this and she tries that. I also improvise. Seeing what I am seeing I do this I do that.",37

\footnotetext{
* Rittman left for America in the summer of 1937 finding work as a concert pianist and as Musical Director of Lincoln Kirstein's Ballet Caravan and later American Ballet Caravanworking with composers, such as Aaron Copland and Leonard Bernstein, and arranging their music for two pianos. When Ballet Caravan disbanded in 1941, Rittman became the accompanist for Agnes de Mille's small dance company and then worked with de Mille on her many Broadway successes. Such was de Mille's high regard for Trude Rittman, as a person and for her work, that she devoted much of a chapter to her in Dance to the Piper. ${ }^{\dagger}$ At Dartington, Cohen was joint artistic director, with Jooss and Leeder, of the Jooss-Leeder School of Dance while also being musical director and chief pianist for the Ballets Jooss. When the company left for America in 1939 he was artistic director shouldering all the demands of the role in the very difficult circumstances in which the company was operating.
} 
Given that Rittman appears to be the link between de Mille and Cohen, it is possible that it was Rittman who recommended de Mille to Cohen as a choreographer who could work with the company, and that she encouraged de Mille to accept the invitation to work with the Jooss Ballet when Cohen approached her, citing, perhaps, the similarities in working methods. ${ }^{*}$ One can see that de Mille may have been reticent to accept the commission; after all, the Jooss Ballet was a very different entity from Ballet Theatre or from her own small company with which she had most recently worked. She may also have been wary of working with non-Americans as she had noted to John Martin that her experience in England had shown her that European dancers did not present her American material satisfactorily. ${ }^{38}$ Perhaps the fact that the Jooss Ballet was held in very high esteem in the New York dance world at that time helped persuade her.

She certainly took the task seriously for she wrote to Sybil Shearer, "I've postponed my California vacation because I think I ought to prepare more carefully my Joos [sic] ballet." ${ }^{, 39}$ This she was right to do for she was taking on a very close-knit company with some of the original dancers from the early1930s still with the company in New York in 1941. As the dancer Joy Bolton-Carter recalled, "we were a very compatible company sharing [a] gypsy life in what we often felt were rather dangerous circumstances. ${ }^{, 40}$ On their recent tour in South America, for instance, the dancers had survived an earthquake in Santiago, Chile, crossed the Andes twice, endured some quite basic accommodation and doubtful food, dealt

\footnotetext{
* This, of course, is conjecture but given that the Jooss Ballet had returned from South America in April 1941 and that Rittman was preparing for a tour there with American Ballet Caravan beginning in June 1941, it is quite likely that Rittman met with her old colleagues to discuss the pros and cons of such an adventure; conversation could have turned to what the Jooss Ballet company was to do next, thus leading to the proposal to approach de Mille.
} 
with limited availability of decent pianos, and coped with varying conditions in theaters. ${ }^{*}$ In addition, as the company had become entirely separate from the Dartington Trust, they were forced to be totally self-sufficient operating as a co-operative. ${ }^{42}$ Surely, with this recent shared experience of an exceptionally hard tour, and with many of the dancers having known each other and worked together for so long, de Mille must have felt an outsider? While this sense of alienation may not have been unfamiliar, it could not have made for comfortable rehearsals.

Perhaps more importantly, the Ballets Jooss dancers shared a dance language unique to those who had studied with Jooss and Sigurd Leeder. The language was synthesized from Jooss's and Leeder's thorough knowledge and experience of Laban's theories and movement principles, the dancers' training in ballet (gained through study in Paris in 1926-27), and each individual's unique dance experiences. Technical virtuosity (such as multiple pirouettes) for its own sake was not part of the movement vocabulary; rather, the intellectual understanding of dynamics, design, the principles of movement, and so on, all affected how the daily barre and center practice were executed, informed movement exploration in improvisation, and movement choices in choreography. ${ }^{\dagger}$ Dancers, including Alfred Corvino, who joined the company in South America, experienced the training through daily company class with Hans Züllig and Lydija Kocers, ${ }^{43}$ and careful induction into the roles they played. De Mille would

\footnotetext{
*See Cohen's description of the company's travels in "The Ballets Jooss Pan-American Pioneers," Dance (July 1941): 10; See Joy (Bolton-Carter) Skinner's memories of that time in her autobiography. Joy Skinner, Over the Hill with a Magic Carpet (Haddenham: Fern House, 1999): 30-37.

${ }^{\dagger}$ For a full explanation of their work see Jane Winearls, Modern Dance: the Jooss-Leeder Method (London: A \& C Black, 1958).
} 
have recognized much of the ballet vocabulary incorporated by Jooss and Leeder, but "central and peripheral movement," for example, or the movement analysis and terminology of eukinetics and choreutics would all have been unfamiliar to her. ${ }^{*}$ However the dance language of de Mille and the modern dance language of the Jooss Ballet dancers might not have been so far apart as might be supposed for de Mille's dance language may have been eclectic and may have been given balletic treatment but, "philosophically she considered herself amongst the moderns." 44

Jooss called his companies Ballets Jooss (or Jooss Ballet) with the sub-title "Dance Theatre" thus removing his work from the expressive movement of German Modern Dance concerts and from the spectacular elements of ballet, and denoting that his was a new form of dance where movement was the medium for drama. Thus Jooss demanded more from his dancers: "His dancers are actors, or his actors are dancers," ${ }^{, 45}$ wrote Mary Watkins, meaning that there should be no movement without motivation. Often his work was character driven and this de Mille may well have recognized as similar to her own sense of theater; she too demanded fine acting from her dancers, ${ }^{46}$ and, as Barbara Barker notes, de Mille herself could be considered "a movement-based actress". 47

Many of the Ballets Jooss dancers had worked with Jooss in creating his ballets—Elsa Kahl and Hans Züllig were members of the first cast for The Green Table and Big City in 1932, for example — while other dancers, including Jack Skinner and Joy Bolton-Carter, were in the original cast of later works such as Chronica and A Spring Tale. These dancers were

\footnotetext{
* Eukinetics is concerned with dynamics and rhythm in movement while Choreutics is concerned with the spatial aspects of movement. See Winearls's chapters on 'Dynamics' and 'Direction and Design' in Modern Dance: the Jooss-Leeder Method (London: A \& C Black, 1958).
} 
accustomed to Jooss's working method; that is, he would come to rehearsal with ideas about narrative and character that he expressed verbally and physically as the dancers improvised. ${ }^{48}$ From this experimentation Jooss would select particular movements, which he would then order, structure, and develop with the dynamics and accents he wanted. Rehearsals then centered on polishing and clarifying technical details for performance. Jooss's ballets then resulted from joint creative processes between the choreographer and the dancers (usually with the composer in the studio creating as the dancers worked), their shared movement vocabulary and movement analysis facilitating the process.

For de Mille, "When starting on a ballet I must know first what I want to say — the emotional ideas. Then I decide on the form of the dance." 49 This was not unlike Jooss's process but, in contrast to Jooss, de Mille liked to prepare in private, with one or two chosen favorites. She was, she said, "struggl[ing] to get the diction, idiom, speech and seed gesture out of which the whole design will grow, ${ }^{, 50}$ thus working out in advance material that she would teach to the dancers. For Drums Sound in Hackensack it seems de Mille tried working with the dancer Marguerite de Anguera, ${ }^{*}$ not a Jooss Ballet dancer but recruited to the company for this New York season, and someone with whom de Mille had worked before.

De Anguera recalled:

True to her style, she asked me to come over to her studio so she could experiment with me. The part was to be danced by Ulla Soederbaum, a very small girl, inches shorter than I. Each time she asked me to do such and such, she would complain that I didn't look like Ulla. Finally I exploded. "Why don't you ask Ulla to come over since this is her part? She is probably at the apartment they all share, with nothing to do and no money to do it with.

\footnotetext{
* De Anguera had spent a very brief time at the Jooss-Leeder School, Dartington, in 1934/35 and had danced for de Mille some time in 1939/40.
} 
I'm sure she would welcome the chance to work with you and I cannot be Ulla!"51

De Mille also approached Sybil Shearer to work with her. ${ }^{*}$ It is clear from her letter to Shearer that she was challenged by Cohen's and Greanin's request that her work for the Jooss Ballet be a comedy:

Sybil dear-Listen carefully! I'm in rehearsal now with the Joos [sic] ballet night and day and I'm doing them a comedy because that's what they wanted. But they're not comedians. Not my kind. And I'm breaking my head and my heart. The work goes so very slowly. Take three steps forward, two backward.

For fifty dollars would you consider coming down for about four days? . . I'm really desperate. If we get something substantial done I would also see that you get program credit.

Do try - otherwise I might have to throw over this ballet and prepare something that involves no pantomime at all. Which would be terribly disappointing and hateful. ... Phone me your answer-reverse charges. ${ }^{52}$

The letter has an edge of desperation to it as if de Mille had tried working with the company but no muse had emerged with whom she could work in her preferred way; Sybil Shearer duly arrived and was credited as "Choreographic Assistant" in the program. ${ }^{53}$

\footnotetext{
* De Mille had worked with Shearer as her muse/assistant before: With only two or three weeks to prepare Three Virgins and a Devil she had worked extensively with her on the dance material for the Devil although, as de Mille freely admitted in her autobiography, most of the movement had come from Shearer. Dance to the Piper, [DO YOU HAVE A PAGE NUMBER FOR THIS INFORMATION?]
} 
De Mille stated, "I do a great deal of planning before rehearsal and start off with pages of notes and diagrams." ${ }^{, 54}$ Fortunately these exist for Drums Sound in Hackensack and cast some light on the movement material. The notes are hand-written and appear to cover the first and last of three episodes. A mixture of verbal description, ballet terms and drawings of spacing and floor patterns, they are similar to notes de Mille wrote for her other ballets, but the sketches for Drums are far from complete. ${ }^{55}$ From my examination, I speculate that these are the notes of her preparatory work with key dancers and they seem to leave open material to be filled in later in rehearsal. Indeed, de Mille described her notes and diagrams "as a sort of self-defense,"* giving her something to fall back on when she was not inspired by some gesture or action given to her by anyone in the studio.

The extract from her notes below reveals that at the time she was writing the choreography, de Mille had assigned the parts - the roles are detailed by the dancer's name rather than the character's name - and had decided the movement vocabulary for each dancer:

Ulla's Part

Ulla and Peter and $\mathrm{Lou}^{\dagger}$

\footnotetext{
*Howard Loxton, “Viewpoint: Agnes de Mille,” Dance Magazine, (April 1965), 60. Anyone other than de Mille would find it difficult to recreate the work from these notes.

†Ulla Soderbaum, Lucas Hoving, and Peter Michael. De Mille had recently worked with Peter Michael, a solo dancer with Ballet Theatre, and she may have requested he be brought into the Jooss Ballet. However the Jooss Ballet had lost three key figures, Rudolf Pescht, Ernst Uthoff and Lola Botka, who had elected to stay in Santiago, Chile where they taught and later organized what became the Chilean National Ballet. The company needed to hire new dancers to take their places, and these included Michael, de Anguera and Milton Feher.
} 
$A$ - three in circle join hands

8 steps to left, grapevine - tiptoe really smooth

B - 4 changements fingers up and inside - playing hands

Repeat A

2 big jumps changement, left knee

Curved arm open and close

A with fingers playing

1 swing rt ft dehors to open to $2^{\text {nd }}$ facing out

2 reverse foot position facing in

3

And stamp right foot and lift it

4 clap

4 [?] walking backwards in sitting position, clap hands on off beat

1 open $2^{\text {nd }}$ lunge forward $r t$ ft

2 lunge forwards left

3 stamp rt ft and lift knee bent

4 close into open $2^{\text {nd }}$ - hands folded on [?]

Quick steps - galliarde

begin facing back

lt cuts through

rt cuts out

Ulla face Lou, Peter back to Ulla 
On $3^{\text {rd }}$ phrase Ulla 4 jumped kicks with locked knees

4 steps in place, pointed toes, turning jetes hands playing

1) 2 counts demi-contretemps $r t$

2)

3 changement hands playing

4 changement

6 opening knee and hand - very rapid

Same ft pointed as hand opens. Lt knee opens first

vamp 1) demi contretemps - back to audience. Towards

2) Rt (stage lt)

3) Finger play no ft movement

4)

4 repeat same to $l t$

The movement vocabulary, an eclectic mix, draws from ballet terminology (“contretemps"), folk dance terms ("grapevine"), and modern dance vocabulary ("lunge"), and everyday language ("walking backwards"). Such variety was not unusual for de Mille as she freely acknowledged incorporating a range of influences in her work, writing, "I try to invent freshly, but one builds upon what one has done." ${ }^{57}$ She borrowed from her own work and drew from her experiences of working with Tudor, Laing, and Shearer, for example. Consciously or unconsciously, de Mille used what she had seen of Graham, Humphrey, and others. For some critics and dancers — such as the dancer Dorothy Bird, for example, who said it was not the borrowing of Graham's material that upset her but the way de Mille "did 
not use the movements as they had been intended," ${ }^{, 58}$-this reworking of others' material was unacceptable.

The notes do not make explicit the ballet's scenario although de Mille stated, “They asked me to make it American ... [so] I chose what I thought might be closest to their background - the Dutch in New Amsterdam. ${ }^{, 59}$ Nor is it evident that the work was comedic, although de Mille's word choice_-“double take”-might suggest a comic element. The extract also does not reveal the speed or dynamics of the movement, whether other dancers were on stage, or how the movement fitted with the music. Given de Mille's statement that, "I'm dependent on music and melody. I can't work without it," was working on his score while de Mille was preparing the movement. We know that Cohen drew on "authentic collections of Dutch folk songs and dance tunes" his material for two pianos (the usual practice of the Ballet Jooss), but there is no way to know how he accessed his source material. The music score is lost, ${ }^{*}$ but reviews describe it as "fine work,"62 "a nice musical score,"63 "satisfactory,",64 and "sure-fire theater music"65 all indicating that the music served its purpose.

It can be supposed from the reviews that the costumes too were acceptable. They were designed by Joep Nicholas, an émigré glass painter from Holland, and realized by Helen Pons, a well-established costumier. ${ }^{\dagger}$ They are variously described as "passable,"66 "amazing

\footnotetext{
* Cohen's papers, housed at the Juilliard Library, have recently been catalogued; no scores for the de Mille ballet have been found.

${ }^{\dagger}$ It seems that Joep Nicholas and his family travelled on the same ship to the US as the Ballets Jooss at the end of 1939. See Claire Nicolas White, Fragments of Stained Glass (New York: New York Creative Publishing, 2015). Although Nicolas had had one or two prestigious exhibitions of his work, it was perhaps Cohen who suggested Nicolas to de Mille as a designer, recognizing him as a fellow refugee in need of work. Drums Sound in
} 
and decorative,"67 and "ingenious." 68 The single drawing design of the costumes that is available ${ }^{69}$ features hats and indicates a color palette of reds/oranges with gray and white. With the only other evidence coming from a few black and white photographs, it is hard to get a sense of what the costumes were like but it can be seen that the Indian Chief wore a large and impressive headdress. Reviews described the men as "brick-red braves,"70 while the women were "Red Indian premonitions, in black wigs, tights, and loincloths."71

The Jooss Ballet's sixth New York season then opened on September 22, 1941 at Maxine Elliot's Theater with the repertory the company had toured for the last eighteen months, although A Spring Tale (a romantic fairy-tale ballet) and Chronica a dance-drama satire on dictatorship * were new to New York. John Martin's review of the first week of that season is remarkable considering the stresses and strains the company had endured in South America: "The Jooss Ballet unquestionably got off to a wonderful start last week ... it shows

Hackensack was Nicolas's only venture into costume design; he was soon employed by Rambusch Decorating Company creating stained glass windows for a number of churches in the US and returning to Holland in the late 1950s. In 1941, Helene Pons was a wellestablished designer/costumier; she had arrived in the US from Russia via France, opened her Studio in New York in 1928 and went on to design and make costumes for many Broadway plays and musicals including Kiss Me Kate (1949) My Fair Lady (1956). See www.helenepons.com where, regrettably, there is no reference to Drums Sound in

\section{Hackensack}

* Chronica (1939) was set in $16^{\text {th }}$ Century Italy and portrays the rise to power of a petty tyrant bringing misery to his people. In the revolt which follows his lover is trampled to death and he is killed by his own soldiers. As was recognised at the time this allegory did not disguise the significance of the story as a blatant comment on the political situation of the time. 
no signs whatever of diminution of powers. It is still perhaps as fine an ensemble as the dance world can boast.",72

Drums Sound in Hackensack premiered on October 2, 1941, third on the program, sandwiched between the Jooss standards A Ball in Old Vienna (light-hearted and humorous) and The Green Table. "Described as a "Dance Comedy" its brief program note reads, "A dooryard of a farm outside New Amsterdam, about 1650.” Walter Terry's synopsis in his review gives more information:

The scene opens on a folk dance scene in which the daughter of the house treads a robust measure with her swain and her brother. Soon a group of extremely red Indians march on with their furs (including a raccoon coat). Dissatisfied with the trading possibilities, they leave, but a wiley half-breed brings them back at pistol point. After a thorough dousing in firewater, the braves are robbed of their furs.

The review continues:

The maid is haunted by a bevy of aboriginal-looking premonitions and her fears are soon realized, for the sobered braves, in war regalia, return and take back their furs, leaving behind them a disgruntled lot of Dutchmen and a half-breed who has snitched a couple of furs for himself. ${ }^{\dagger}$

\footnotetext{
* Its position in the program varied from performance to performance; it was either first, second or third, but last only once - this spot was always reserved for The Green Table when it was in the program.

${ }^{+}$Walter Terry, “Jooss Troupe Bases Ballet on Life of Settlers," Herald Tribune, October 3, 1941. This is the clearest description of the work in any of the reviews or articles found.
} 
Although it is not clear in Terry's description, the work was in three scenes or episodes with the central scene (the premonitions) a "ballet within a ballet." Nor does the description make clear how the work was comic although Terry stated that there were, "hilarious moments of comic characterization"74; John Martin wrote of "flashes of delightful humour here and there"75; and George Beiswanger wrote of the way de Mille united comic inventiveness, "with a seriousness that has never before come so clearly to the surface."76 Bolton-Carter also commented on the humor, reflecting perhaps how different de Mille's humor was from her own, writing: "[Ulla] is the only serious character in the ballet. The rest one might term American-type slapstick as the audience laughs as it would at Laurel and Hardy."77 It would seem then that de Mille had succeeded in fulfilling Cohen's initial request for a comedy.

The critics were unanimous in their praise of Ulla Soederbaum in the main role of The Daughter of the House describing her as, "thoroughly charming"; "remarkably attractive . . . technically expert and authoritative" ${ }^{78}$; and, "delightful ... an expert pantomimist as well as brilliant technician." ${ }^{, 79}$ Others in the cast were described as "danc[ing] with a will" ${ }^{, 80}$ and as "g[iving] of their best." ${ }^{\wedge 1}$ Hans Züllig, the only other dancer selected for individual comment, was described as "excellent" 82 and "splendid" 83 in his role as A Half Breed."

On the choreography opinion was more divided, especially about the middle section: "There is a long and vague center section dealing with premonitions of Indians which lets it

\footnotetext{
* This term, in use since the $17^{\text {th }}$ century-the time at which the ballet was set-was used to describe people who were half Native American and half European. Although many today would find the term offensive, de Mille's usage was not unusual for the time. See for example the film The Half-Breed (1952) which was set about the same time and had a similar story (greedy, white traders profiting through tricking Native Americans) to Drums Sound in

\section{Hackensack.}


down badly" wrote Terry. ${ }^{84}$ Martin agreed: "The only weak spot in the whole ballet is the premonition scene. In spite of much splendid movement pattern, the fantastic Indian maidens who haunt the young Dutch girl's dreams are on stage much too long for the purpose of the theme. Half the length or less would find this episode more effective as pure dance and of greater power in the progression of the story. $" 85$ In contrast, another anonymous critic's view was that the Unhappy Premonitions scene was, "especially fine" with its blend of ballet and contemporary styles of movement skillfully done. ${ }^{86}$

On the whole, the reviews were positive, with Edwin Denby declaring the ballet "a hit," $" 87$ although Martin called it "an interesting rather than a successful experiment." ${ }^{, 88} \mathrm{He}$ continued that the work could benefit from "copious cutting" and that the simple Jooss approach needed to take command of material that was "too stagey." He concluded that, "then things are pretty certain to take a turn for the better." However, I have seen no evidence to suggest that any further work was done on the ballet; it was performed only during this season, with some twenty or so performances over three weeks at Maxine Elliot's Theater, one week in Philadelphia at the Locust Street Theater, and two further weeks at the Windsor Theater, New York.

It is interesting to consider how this forgotten work helped the Jooss Ballet and what de Mille gained from the experience of working with the company. Joy Bolton-Carter recognized the significance of de Mille to the company writing, "We were saved by Agnes de Mille ... compos[ing] a new Ballet for us." ${ }^{\text {89 }}$ The company had been desperate for something new to work on, Bolton-Carter said, having been dancing the same repertory week in, week out, for the best part of eighteen months. The dancers needed to be challenged intellectually, physically and artistically. ${ }^{*}$ With her female perspective and American heritage, novel

\footnotetext{
* This is evidenced through their work on a collective composition by the whole company, directed by dancer Lucas Hovinga [sic], entitled News Reel. It was mentioned frequently in
} 
working process, different movement vocabulary, and unique aesthetic de Mille provided this challenge. Beiswanger observed the change was a positive:

Commentators rightly noticed the presence of something different—de Mille's emphasis on solo dancing, a suggestion of virtuosity. ... Observing how eagerly and successfully the group took to the new work, it would be a mistake to regard these as intrusions alien in purpose and style. On the contrary, they seem a logical extension in range. ... New ways are always dangerous, but with a company so well-grounded in manner and so solidly integrated as a performing group there is decided point in appropriating an added sum of theatrical dancing. ${ }^{90}$

For her part, de Mille worked with a highly trained, highly regarded professional company with a reputation to maintain. Unquestionably, the project allowed her to hone her choreographic skills while working with unfamiliar dancers who had their own movement language and working methods. Perhaps this caused her to reflect on her creative and rehearsal processes as well as her interpersonal skills in communicating with such diverse nationalities in a close knit company. Undoubtedly these experiences served her well when she came to her next major project, that of reworking her Rodeo for the Ballet Russe de Monte Carlo the following year.

It may have been of great use to her also to have choreographed for a large company of twenty dancers as most of her previous experience had been in creating solos for herself, or duets, or for a small group. Nine dancers in the Jooss Ballet were male; strange, then, that de Mille, recollecting the start of rehearsals with the Ballet Russe de Monte Carlo in the the pre-publicity but does not appear to have been given in public. Cohen also spoke of the company's desire for Kurt Jooss to bring them other works from their repertory (such as The Mirror or Johann Strauss Tonight! perhaps) or to create a new work for them. See "The Ballets Jooss Pan-American Pioneers,” Dance (July 1941). 
summer of 1942, should write, "It occurred to me at this precise moment that with the exception of five male soloists I had never worked with men in my life." ${ }^{91}$ Clearly this was not the case, but the erasure may not be so surprising given that de Mille appeared to have expunged Drums Sounds in Hackensack from her memory while writing her memoir, Dance to the Piper. She did not forget the Jooss dancers entirely, however, as Lidija Kocers (Franklin), for example, went on to work with her frequently, on Broadway in Bloomer Girl (1944), in Brigadoon (1947), and became a member of the Agnes de Mille Dance Theater (1953-54). In time, the other Jooss dancers could reflect on the experience of working with de Mille, realizing that they had worked with a woman who was to become a few years later "the best-known choreographer in the world.",92

It is also of value to conjecture how Drums Sound in Hackensack may have fitted in de Mille's development as a choreographer. Barbara Barker identified that, "in the 1930s she [de Mille] focused primarily on works about women, women alone and in community." $" 93$ Indeed, in Drums de Mille featured "the daughter of the house" as seen alone and in her community. ${ }^{*}$ It would seem also that we see the narrative "through the eyes of the heroine rather than with an objective view of a series of characters. ${ }^{, 94}$ Barker, and later Shelly Berg, ${ }^{95}$ identify the autobiographical nature of de Mille's heroines, writing of the way they are often "out of step" with those around them. Beiswanger suggests their misfit status might be seen in this work, too, as “"the daughter of the house' ... senses, as her uncles, ... do not, the wickedness of this robbery, the gentle and mysterious beauty that is being trampled on, the retribution that impends." ${ }^{, 96}$ She may not be as feisty as the heroine in Rodeo but there is still a quality that marks her out from the other characters, a willingness to stand up for what she believes to be right. It is not too big a jump to link this to Barker's description of de Mille's

\footnotetext{
* This focus on female characters continued in works such as her ballet Fall River Legend (1947) based on the life of Lizzie Borden and in the musical Bloomer Girl (1944).
} 
personal characteristics of "holding implacably to her artistic vision and a refusal to compromise." ${ }^{, 97}$ There are several indications that de Mille may have danced the main role at some point. ${ }^{*}$ Martin seems to have noted the similarities between the character and her creator, writing that, "the role compels her [Soederbaum] to dance Miss de Mille's personal style instead of her own." 98 These clues point to the notion that there may be autobiographical elements in the work if de Mille was creating something that she wished to dance herself.

Scholars and critics have identified several prominent themes across de Mille's work, a number of which emerge in Drums. Barker focuses on the American themes in de Mille's work of the 1930s. With its story of Dutch settlers in conflict with Native Americans set in the mid- $17^{\text {th }}$ century, it is possible to see that de Mille continued with this theme in Drums Sound in Hackensack so that, "[It] emerged as a truly American dance piece in both theme and flavor." 99 Perhaps, then, the work may be seen as a link between de Mille's solo and small group explorations of American themes in the 1930s and her larger scale works of the 1940s which drew on de Mille's perception of Americana. Shelly Berg identifies “dream-like settings" $" 100$ as an element of de Mille's most successful choreographic works. Just such a device occurs in the second scene (the premonitions) of Drums where, in the "dream ballet," the character of the main protagonist is developed, giving the audience further insight into her psyche, and helping to further the plot. Might this scene, albeit unsuccessful according to many critics, be seen as a pre-cursor to Laurie's dream in Oklahoma!?

\footnotetext{
* Lucas Hoving recalled that de Mille performed in Drums Sound in Hackensack and that he had worked specifically with her on the lifts. See Billie Mahoney, Dance On: Lucas Hoving, interview (New York: Insight Media, 1986). There is also a note in the New York Sun, October 22, 1941 announcing that de Mille would dance the role but no reviews of her performance(s) have been found.
} 
Berg also describes de Mille's "unerring sense of theatricality."101 In his review, Walter Terry reveals how de Mille achieved theatricality in Drums: "Miss de Mille has a way of investing folk material with theatrical zip while at the same time retaining its guileless simplicity.... [She] has smoothly welded together these various episodes to the point where it seems quite natural for a dance of the drunken Indians to follow a gay folk dance, and for a dance fantasy of a dream-like premonitions to emerge from a warriors brawl." ${ }^{\text {"102 }}$ Terry highlights de Mille's eclectic dance vocabulary which she had woven into a theatrical whole. Might this too be seen as a precursor to the 1942 Rodeo, with its material drawn from riding and roping techniques, traditional American folk dances, ballet and tap dancing?

A key aspect identified by Beiswanger in the mid-1940s was de Mille's ability to define and convey character through gestures: "[she] is fertile in their invention, crafty in their use. They give bite to her satire, point and often poignancy to her humor. Gesture themes bind her ballets together and punctuate the syntax." ${ }^{103}$ In de Mille's choreographic notes, as in the extract above, for example, there are several references to "hands play" and “fingers play" as recurring motifs, ${ }^{*}$ suggesting that de Mille was already exploring gesture as a key aspect of her choreography. This was certainly something that de Mille developed in her choreography for Oklahoma!, for example. Later de Mille was to acknowledge the importance of gesture, noting, "I may see someone .. . make some spontaneous accidental gesture. And the gesture will become the key on which the choreography of the whole ballet depends."105

It is possible to see that Drums Sound in Hackensack had its place in de Mille's choreographic development. However the artistic and public success de Mille longed for was

\footnotetext{
*Shelly Berg, "Saving a legacy: Agnes de Mille’s Gold Rush,” Dance Research 19, no.1 (April 2001): 88. Berg notes that "the use of hands is a favourite gesture motif of de Mille."
} 
still some months away and, when the Jooss Ballet season finished in early November 1941, she was already on tour with her small company in the Midwest ${ }^{*}$ during which she premiered a short recital piece called Night Scene in Chicago. ${ }^{106}$ When the company "fizzled out for good," ${ }^{107}$ de Mille returned to New York, took class regularly, taught her Acting for Dancers course, and wondered what was to become of her. On December 7, the Japanese bombed Pearl Harbor and within days the US was at war with Japan, Germany, and the Axis powers.

Unlike in the UK, when theaters closed immediately at the outbreak of war, theaters in the US stayed open and life continued much as usual for civilians. Cohen managed to secure work for the Jooss Ballet from January to March 1942 performing in shared programs with the Boston Comic Opera Company at the St. James' Theater, New York; The Green Table shared a bill with Gilbert and Sullivan's HMS Pinafore, Prodigal Son with The Pirates of Penzance, and Big City and A Ball in Old Vienna with The Mikado. It is hard to imagine how these works sat happily together on a program, but as Robert Bagar noted of the opening night, "What can't be overlooked is that last night's was a corking good show... . The gathering enjoyed it, but definitely." 108 Also, as Bagar suggests, perhaps The Green Table had gained some new resonance for its audience now that the country was at war.

However, even this shared season could not save the company and it disbanded, leaving the dancers to find work where they could. Some elected to stay in the US. Lucas Hoving, for example, while he continued to work with de Mille, went on to dance with Graham, and later, most notably, with José Limón. Some, including Hans Züllig and Joy Bolton-Carter found their way back to England to re-join Jooss, who found himself with support from the Council for Encouragement of Music and the Arts (CEMA) and, thus, in a

\footnotetext{
* This tour adds to the confusion over whether or not de Mille danced in Drums Sound in Hackensack; the New York Sun report suggests de Mille's performance was imminent but the tour dates allow a window of only a few days in which she could have danced it.
} 
position to reform his Ballets Jooss. Frederick Cohen and his wife, the dancer Else Kahl, stayed in the US, teaching at Black Mountain College."

By the middle of 1942, things were looking up for de Mille. She had secured the job of choreographing Rodeo for the Ballet Russe de Monte Carlo which premiered later that year. Not only was her choreography widely praised but her performance in the main role earned her the accolades she had longed for. After that success, her work on Oklahoma! (premiered March 31 1943) shot her to stardom, critical acclaim, and financial stability, and allowed her to take her place on Broadway and in the dance world. It is heartening to think that the forgotten Drums Sound in Hackensack and de Mille's experience working with the Jooss Ballet may have played some part in that success.

Acknowledgements: This research was made possible by a project grant from the Arts Faculty, University of Wolverhampton to enable visits to the Dance Collection at New York Public Library. I am grateful to Linda Murray, the Dance Curator, for permitting access to the Agnes de Mille Papers. I am also indebted to Corrine Pierog, Consulting Program Director at the Morrison Shearer Foundation, for her help in locating letters between de Mille and Sybil Shearer, and to Professor Jonathon Prude for permission to quote from de Mille's choreographic notes.

1. Fernau Hall, Modern English Ballet (London: Melrose Ltd., 1948), 187.

\footnotetext{
* This marked the end of Cohen's and Kahl's long association with the Ballets Jooss. They remained at Black Mountain College until 1944, moving to New York when Cohen accepted a post at Juilliard as director of the Opera Theater.
} 
2. Francois Lafitte, The Internment of Aliens (London: Penguin Books, 1940), 154.

3. Agnes De Mille, Dance to the Piper, (New York: Da Capo Press, 1951),174.

4. A.V. Coton, The New Ballet (London: Denis Dobson, 1946), 73.

6. Kurt Jooss, Biographical note, c1975 quoted in Anna and Hermann Markard, Jooss

(Cologne: Ballett-Buhnen-Verlag Rolfe Garske, 1985), 53. For a full biography of Jooss and his work see Patricia Stöckemann, Etwas Ganz Neues Muß Nun Entstehen: Kurt Jooss Und Das Tanztheater (Munich: K. Kieser Verlag, 2001); there is a brief mention of de Mille and Drums Sound in Hackensack. For a biography of Sigurd Leeder see Grete Müller, Sigurd Leeder: der Tänzer als Zeichner (München: K. Kieser Verlag, 2001).

7. John Martin, “War Satire,” New York Times, October 2, 1932.

8. John Martin, “Kurt Jooss Ballet Cheered at Debut,” New York Times, November 1, 1933; John Martin, “Art of Jooss,” New York Times, November 5, 1933; John Martin, “Jooss says Dance is not propaganda," New York Times, November 11, 1933.

9. De Mille, Dance to the Piper, 219.

10. John Martin, quoted in de Mille, Dance to the Piper, 118.

11. Markard, Jooss, 79.

12. Michael Young, The Elmhirsts of Dartington (Totnes: The Dartington Hall Trust, 1996), 226.

13. Victor Bonham-Carter, Dartington Hall-The history of an Experiment (London: Phoenix House, 1958), 130.

14. Ibid., 130.

15. Ibid., 131. For a full picture of dance activities at Dartington see Larraine Nicholas, Dancing in Utopia: Dartington Hall and its Dancers (London: Dance Books, 2007). 16. Bonham-Carter, Dartington Hall, 124-135. 
17. Clare Lidbury, "Whoever Pays the Piper Calls the Tune: Kurt Jooss, Public Subsidy, and Private Patronage," Dance Research, 36, no. 1 (2018).

18. Martha Graham, letter to Dorothy Elmhirst, (undated), Dartington Archive [DWE/A/8/E]. 19. Dorothy Elmhirst, letter to Agnes de Mille, November 18, 1932, Dartington Archive [DWE/A/8/E].

20. Arnold Haskell, Balletomania (London: Victor Gollanz, 1934), 222.

21. Ibid., 127. Later, in the revised edition (London: Penguin Books, 1979), 198-199, Haskell amended his opinion for the better.

22. Peggy van Praagh, "Working with Anthony Tudor," Dance Research, 11, no. 2 (1984): 59.

23. Carol Easton, No Intermissions: the life of Agnes de Mille (New York: Little Brown \& Co., 1996), 150.

24. Ibid., 169.

26. “The Ballets Jooss Pan-American Pioneers,” Dance (July 1941): 10, 19.

27. Ibid., 10.

28. Easton, No Intermissions, 173.

29. Ibid., 174.

30. Peter Kihss, "Miss De Mille to write a Ballet Satire," New York World Telegram, September 29, 1941.

31. Jenifer Jones Cavenaugh, “A Composer in her Own Right," in Women in American Musical Theater, ed. Bud Coleman and Judith Sebesta (Jefferson, NC: McFarland \& Co., 2008), 77-89.

32. Trude Rittman, Interview with Trude Rittman [sound recording], 1976 Oral History Project, *MGZTC 3-1187, Dance Collection of New York Public Library. 33. Ibid. 
34. Ibid.

35. Frederick Cohen, "Ballets Jooss: Theatre de la danse," Ballets Jooss Souvenir Program, 1937

36. Raphael de Gubernatis, "Hans Züllig: Souvenirs de La Table Verte," Le Programme de la Deuxieme Biennale Internatinales de la Danse de Lyon, (1986): 29.

37. Rittman, recorded interview.

38. John Martin, New York Times, September 26, 1937, quoted in Barbara Barker, "Agnes de Mille, Liberated Expatriate, and the American Suite 1938," Dance Chronicle, vol. 19, no. 2 (1996): 128

39. Agnes de Mille, letter to Sybil Shearer, July 13, 1941, courtesy of the Morrison Shearer Foundation.

40. Joy Skinner, Over the Hill with a Magic Carpet (Haddenham: Fern House, 1999), 35.

(Joy Bolton-Carter married fellow dancer Jack Skinner and wrote under her married name.)

42. "The Ballets Jooss Pan-American Pioneers,” 19.

43. Dawn Lille, Equipoise, the life and work of Alfredo Corvino (New York: Dance and Movement Press, 2010), 24.

44. Barker, “Agnes de Mille,” 118.

45. Mary F. Watkins, "Five faces of the Dance," Theatre Arts, vol. 18, no. 2 (February 1934): 139.

46. Howard Loxton, "Viewpoint: Agnes de Mille,” Dance Magazine, (April 1965): 61.

47. Barker, “Agnes de Mille,” 140.

48. Friderica Derra de Moroda, "The Dance of the Future by Kurt Jooss," The Dancing Times (August 1933): 454.

49. Loxton, "Viewpoint," 60.

50. Ibid., 60 . 
51. Marguerite de Anguera, What I did to Dance: the inside story (Princess Anne, Maryland: Linden Hill Ltd Publishing, 2002), 97.

52. Agnes De Mille, letter to Sybil Shearer, August 25, 1941, courtesy of the Morrison Shearer Foundation.

53. Jooss Ballet Program, October 1941, Maxine Elliot's Theater, New York, Performing Arts Research Collections - Dance (*MGZB), New York Public Library. 54. Loxton, "Viewpoint," 60.

55. Drums Sound in Hackensack, (s) *MGZMD 37 100-635, Agnes de Mille Collection, New York Public Library.

57. Agnes de Mille, letter to Robert Lawrence at the New York Herald Tribune, May 1943, (unpublished) in response to his review of Oklahoma! quoted in Easton, No Intermissions, 209.

58. Dorothy Bird, Bird's Eye View (Pittsburgh: University of Pittsburgh Press, 1997), 167.

59. Kihss, Ballet Satire. The narrative is a product of de Mille's imagination rather than being based on any one historical event.

60. Loxton, "Viewpoint," 43.

61. Jooss Ballet program, October 1941.

62. Walter Terry, “Jooss Troupe Bases Ballet on Life of Settlers," Herald Tribune, October 3, 1941.

63. John Martin, "World premiere by Jooss Ballet: Drums Sound in Hackensack by Agnes de Mille, Presented for the First Time Here," New York Times, October 3, 1941.

64. "Jooss Ballet,” Dance Observer, November 1941.

65. Robert Lawrence, “Two Piano Ballet,” New York Herald Tribune, Oct. 5, 1941.

66. "Jooss ballet".

67. Martin, "World Premiere". 
68. Terry, "Jooss Troupe".

69. Joep Nicolas, 1 drawing; 1941(?) ink and gouache, 27 x $38 \mathrm{~cm}$. New York Public Library [*MGZGA Nic J Dru 1].

70. “Jooss Ballet," Time, October 20, 1941: 52.

71. Skinner (Bolton-Carter), Over the Hill, 39.

72. Martin, "World Premiere".

74. Terry, “Jooss Troupe".

75. Martin, "World premiere".

76. George Beiswanger, "Dance Theater and Theater Dance; Ballets Jooss and Monte Carlo," Theater Arts 30, no. 12 (December 1941): 895.

77. Skinner (Bolton-Carter), Over the Hill, 38-39.

78. Martin, "World Premiere".

79. “Jooss Ballet,” Dance Observer, November 1941.

80. Ibid.

81. Terry, "Jooss Troupe".

82. Martin, "World Premiere"

83. Terry, "Jooss Troupe".

84. Terry, “Jooss Troupe".

85. Martin, "World Premiere".

86. “Jooss Ballet,” Dance Observer, November 1941.

87. Edwin Denby, "Kurt Jooss; The Monte Carlo Ballet," Modern Music November 1941 in

Edwin Denby, Dance Writings and Poetry, ed. Robert Cornfield (New Haven: Yale

University Press 1989), 57.

88. Martin, "World Premiere".

89. Skinner (Bolton-Carter), Over the Hill, 38. 
90. Beiswanger, Ballets Jooss, 897-898.

91. De Mille, Dance to the Piper, 284.

92. Easton, No Intermissions, 266.

93. Barker, “Agnes de Mille,” 140.

94. Ibid., 141.

95. Shelley Berg, "Saving a legacy: Agnes de Mille's Gold Rush” Dance Research 19, no. 1 (April 2001): 84

96. Beiswanger, "Ballets Jooss,” 895.

97. Barker, “Agnes de Mille,” 120.

98. Martin, "World Premiere".

99. Terry, "Jooss Troupe".

100. Berg, "Saving a legacy," 74.

101. Ibid., 64.

102. Terry, "Jooss Troupe.”

103. George Beiswanger, "New Images in Dance: Martha Graham and Agnes de Mille"

Theater Arts 28, no. 10 (October 1944): 613.

105. Loxton, "Viewpoint," 60.

106. Easton, No Intermissions, 484.

107. Ibid., 179.

108. Robert Bagar, no title, New York World Telegram, January 22, 1942.

CLARE LIDBURY is reader in Dance at the University of Wolverhampton, UK. Her dance practice and teaching is based in her inheritance of the Jooss-Leeder work, while her research, focusing on the work and legacy of Kurt Jooss and his partner Sigurd Leeder, and their debt to the work of Rudolf Laban, has been published in Dance Research, 
Conversations Across the Field of Dance Studies, Choreologica, and Research in Dance Education. 